\title{
Isolation and Purification of Organophosphorus Hydrolases Secreted from Acetone-acclimated Phosphorus Accumulating Organisms and Study of Their Properties for Hydrophobic Organophosphorus Sensor
}

\author{
Zixian Guo,* Hong Hua QuAn,* Chuanpin Chen,** Cheng Zeng,*** Zhijuan QIAN, ${ }^{* * *}$ and \\ Ming LI*† \\ *College of Environmental Science and Engineering, Yangzhou University, Yangzhou 225127, P. R. China \\ **Department of Pharmaceutics, School of Pharmaceutical Sciences, Central South University, Changsha \\ 410013, P. R. China \\ ***Yangzhou Customs District, Yangzhou 225000, P. R. China
}

\begin{abstract}
The present work studied an acclimation method for phosphorus accumulating organisms (PAOs) with a high content of acetone in culture solutions to develop microbial-based enzyme sensors for highly hydrophobic organophosphorus (OP) pesticides. Through three steps of cultivation and acclimation, only rod-shaped bacteria survived among the various PAOs. The extracellular enzymes released from the acclimated PAOs were salted out by using ammonium sulfate, then purified by a dialysis membrane and a DEAE-Sepharose FF anion exchange column. Two enzyme components were successfully separated-both of which showed hydrolase activity on disodium $p$-nitrophenyl phosphate (enzyme I, $1.57 \mu \mathrm{mol} /(\min \cdot \mu \mathrm{g})$; enzyme II, $0.88 \mu \mathrm{mol} /(\min \cdot \mu \mathrm{g})$ at $\left.45^{\circ} \mathrm{C}\right)$. Further, SDS-PAGE gel electrophoresis results showed that the molecular weights of enzymes I and II were about 15.11 and $11.98 \mathrm{kDa}$, respectively. On this basis, the applicability of the enzyme in hydrophobic OP biosensors was demonstrated.
\end{abstract}

Keywords Phosphorus-accumulating organism, extracellular enzymes, isolation, purification, enzymatic properties, biosensor

(Received January 1, 2021; Accepted February 11, 2021; Advance Publication Released Online by J-STAGE February 19, 2021)

\section{Introduction}

Organophosphorus (OP) compounds are used as pesticides, insecticides, and chemical warfare agents and are among the most toxic substances known. Researchers have made efforts to exploit effective methods to quantitate the concentration of OPs. The most commonly used methods for OP quantification are chromatography coupled with different detectors. ${ }^{1-6}$ Although the resolution and sensitivity of these techniques are excellent, the processes are time-consuming and not amenable to on-line process monitoring. Biological methods including biosensors based on immunoassays and inhibition of cholinesterase activity for OP determination have also been reported. ${ }^{7,8}$ Biosensors based on acetylcholinsterase (AChE) inhibition using AChEmodified amperometric, potentiometric, conductometric, or fiber optic transducers have been extensively studied. These sensors require a long incubation time with inhibitors prior to analysis and low selectivity due to inhibition from many other compounds.

Besides, there are several kinds of enzymes used to make OP biosensors, such as organophosphate hydrolase (OPH), ${ }^{9}$ organophosphate acid hydrolase (OPAA) ${ }^{10}$ and methylparathion hydrolase (MPH). ${ }^{11}$ Of these, OPH has been shown to effectively

† To whom correspondence should be addressed.

E-mail: liming@yzu.edu.cn hydrolyze a range of OPs and provide advantages in the detection scheme based on monitoring the OPH-catalyzed hydrolysis products. ${ }^{12,13}$ It offers the advantages of simpler, more direct, and quicker measurements of only the OPs herbicides. To date, OPHs have been isolated and purified from a range of bacteria like Flavobacterium, ${ }^{14}$ Pseudomonas, ${ }^{15}$ and Cladosporium. ${ }^{16}$ Phosphorus accumulating organisms (PAOs) are widely applied for phosphorus removal in wastewater treatment because they convert excessive phosphorus into soluble phosphates under stressed anaerobic conditions. ${ }^{17,18}$

Our pilot study showed that PAOs are also excellent OPH donors for OP degradation with no special stimulator in aerobic conditions. Nevertheless, the analysis of water-insoluble OPs, like phoxim, is still problematic with enzyme-based methodologies due to their poor solubility in aqueous solutions; there are few studies on this topic. ${ }^{12}$ Many OP pesticides are insoluble in water, but soluble in organic solvents. Increasing the content of an organic solvent in the solution system can solve this problem; however, the addition of organic solvents would have a great impact on the survival of PAOs. In the presence of organic solvents, many bacteria and their enzymes would be destroyed and inactivated, which limits the application of biotransformation in chemical applications. ${ }^{19}$ A feasible solution is to use organic solvent-resistant bacteria as biocatalysts. Increasing numbers of bacterial strains that can adapt to toxic organic solvents have been isolated and characterized..$^{20-22}$ However, there is no report on the separation 
and purification of PAOs and their extracellular enzymes that are resistant to organic solvents.

In this study, an acclimation method for PAOs with a high content of acetone was investigated. This work details an isolation and purification method as well as the properties of hydrophobic OP degradation; we investigated the applicability of the enzymes for sensors of hydrophobic OP pesticide residues.

\section{Materials and Methods}

\section{Chemicals and reagents}

Phoxim, methamidophos, dimethoate, ammonium sulfate, Tris-HCl, $p$-nitrophenol (pNP), disodium $p$-nitrophenyl phosphate (pNPP), bovine serum albumin (BSA), and glutaraldehyde were purchased from Argentina Latin Reagent Co., Ltd. Dipotassium hydrogen phosphate and acetone were purchased from Sinopharm Chemical Reagent Co., Ltd. Dialysis bags (MW6000) were obtained from Beijing Mengyimei Biotechnology Co., Ltd. DEAE-Sepharose FF was purchased from Tianyan Biotechnology Co., Ltd. Nylon membrane (0.8-nm) was purchased from Shanghai Xinya Purification Device Factory. A pH meter was purchased from Shanghai Russell Technology Co., Ltd. All chemical solutions were stored in a refrigerator at $4^{\circ} \mathrm{C}$.

\section{Strains and cultivation, acclimationof PAOs}

The PAO strain was purchased from Anhui Quanmin Environmental Technology Co., Ltd., China. Phosphoruscontaining culture medium is as follows: $\mathrm{C}_{4} \mathrm{H}_{5} \mathrm{NaO}_{4}: 0.80 \mathrm{~g}$, $\left(\mathrm{NH}_{4}\right)_{2} \mathrm{SO}_{4}: 0.05 \mathrm{~g}, \mathrm{KH}_{2} \mathrm{PO}_{4}: 0.25 \mathrm{~g}, \mathrm{MgSO}_{4} \cdot 7 \mathrm{H}_{2} \mathrm{O}: 0.125 \mathrm{~g}$, $\mathrm{NaCl}: 0.125 \mathrm{~g}, \mathrm{FeSO}_{4} \cdot 7 \mathrm{H}_{2} \mathrm{O}: 0.0025 \mathrm{~g}, \mathrm{MnSO}_{4} \cdot 4 \mathrm{H}_{2} \mathrm{O}: 0.0025 \mathrm{~g}$, and deionized water: $1 \mathrm{~L}$. Solid medium was prepared by adding $20 \mathrm{~g}$ of agar to the above phosphorus-containing culture medium. The process of the PAOs culture was as follows: PAOs were cultured in $\mathrm{pH} 7.2$ phosphorus-containing culture medium at a constant temperature $\left(28^{\circ} \mathrm{C}\right)$ and oscillated at a speed of $160 \mathrm{r} / \mathrm{min}$. The growth of the strain reached the stationary phase after $28 \mathrm{~h}$. To the PAO culturing medium in the stationary growth period, we added a $10 \%$ total volume of acetone and acclimatized the PAOs for $24 \mathrm{~h}$. It was then placed on a solid medium for further diffusion culture. Acetone was then added accounting for $60 \%$ of the total volume of the PAO liquid in the stable growth stage after a diffusion culturing for secondary acclimatization.

\section{Preparation of crude enzyme solution}

Here, a $500 \mathrm{~mL}$ of bacterial solution was centrifuged for $30 \mathrm{~min}$ at $4000 \mathrm{r} / \mathrm{min}$. Next, we removed the supernatant, added $5 \mathrm{~mL}$ of $0.2 \mathrm{mg} / \mathrm{L}$ methamidophos to the centrifuge tube, let it stand for $1 \mathrm{~h}$ at $4{ }^{\circ} \mathrm{C}$, and then centrifuged it again for $10 \mathrm{~min}$ at $8000 \mathrm{r} / \mathrm{min}$. The supernatant was treated with a $60 \%$ ammonium sulfate solution for $2 \mathrm{~h}$ at $4^{\circ} \mathrm{C}$ and centrifuged for $20 \mathrm{~min}$ at $10000 \mathrm{r} / \mathrm{min}$; then, the remaining precipitate was dissolved in a $0.05 \mathrm{~mol} / \mathrm{L} \mathrm{pH} 8.0$ Tris- $\mathrm{HCl}$ buffer solution. The same Tris- $\mathrm{HCl}$ buffer solution was added to a beaker, and the salted-out protein was placed into a dialysis bag (dialysis bag repeatedly rinsed with water before use) for dialysis. We changed the buffer solution every $12 \mathrm{~h}$ and repeated this three times. Finally, we put the dialysis bag into a $30 \%$ polyethylene glycol solution to obtain an appropriate concentration of crude enzymes.

DEAE-Sepharose FF anion exchange chromatography and SDSPAGE of the crude enzyme

First, we equilibrated the DEAE-Sepharose FF ion exchange column with a $0.05 \mathrm{~mol} / \mathrm{L} \mathrm{pH} 8.5$ Tris- $\mathrm{HCl}$ buffer solution. Next, we slowly loaded the enzyme sample $(1 \mathrm{~mL})$ at a flow rate of $0.25 \mathrm{~mL} / \mathrm{min}$. Then, we eluted with a $0.05 \mathrm{~mol} / \mathrm{L}$ Tris- $\mathrm{HCl}$ buffer containing $0.5 \mathrm{mmol} / \mathrm{L} \mathrm{NaCl}(\mathrm{pH} 8.5)$ at a flow rate of $0.25 \mathrm{~mL} / \mathrm{min}$. The fractions of the protein peaks with enzyme activity were collected for later use.

To perform SDS-PAGE of the crude enzyme an anode, a cathode, a gel buffer, and a certain concentration of acrylamide storage solution were prepared in accordance with Tables S1 and S2 (Supporting Information).

Gel preparation. Similar to general SDS-PAGE protocol, separating gels and concentrated gels were prepared according to the data given in Table S3 (Supporting Information).

Sample preparation. The sample was thoroughly mixed with a loading buffer $(4 \mathrm{~mL} 10 \%$ SDS, $1 \mathrm{~mL} \beta$-mercaptoethanol, $2.5 \mathrm{~mL} 87 \%$ glycerol, $0.1 \mathrm{mg}$ bromophenol blue, $1.6 \mathrm{~mL}$ $1 \mathrm{~mol} / \mathrm{L}$ Tris- $\mathrm{HCl}$ diluted with water to $20 \mathrm{~mL}$, final $\mathrm{pH}$ of 6.8 ) according to a mass fraction of $1: 1$ and boiled for $3-5 \mathrm{~min}$.

Electrophoresis. The inner and outer tanks of the Bio-Rad electrophoresis instrument (Jinan Qiansi Biotechnology Co., Ltd.) were filled with cathode and anode buffers, respectively (Table S1). Then, a constant voltage of $40 \mathrm{~V}$ was applied for about $30 \mathrm{~min}$. When the sample entered the separation gel, we increased the voltage to $100 \mathrm{~V}$ for about $2 \mathrm{~h}$.

Dyeing. To fix the sample band the electrophoresis gel was treated with $40 \%(\mathrm{v} / \mathrm{v})$ ethanol and $10 \%(\mathrm{v} / \mathrm{v})$ acetic acid for $10 \mathrm{~min}$, and rinsed with deionized water for $10 \mathrm{~min}$. Then, it was immobilized with a mixture solution of $0.05 \mathrm{wt} \%$ glutaraldehyde, $0.037 \mathrm{wt} \%$ formaldehyde, and $40 \% \quad(\mathrm{v} / \mathrm{v})$ ethanol for $5 \mathrm{~min}$, and rinsed with $40 \%(\mathrm{v} / \mathrm{v})$ ethanol and deionized water for $20 \mathrm{~min}$. Next, the sample was sensitized with $0.02 \mathrm{wt} \%$ sodium thiosulfate for $1 \mathrm{~min}$, rinsed with deionized water twice, and then stained with $0.1 \mathrm{wt} \%$ silver nitrate solution for $20 \mathrm{~min}$. Finally, a mixture solution of sodium carbonate $(2.5 \mathrm{wt} \%)$ and formaldehyde $(0.02 \mathrm{wt} \%)$ was applied to develop the color to the required contrast (several minutes). Acetic acid solution $(5 \%, \mathrm{v} / \mathrm{v})$ was used to stop the color development.

\section{Determination of the isoelectric point of enzymes}

Here, 13 portions of $100 \mathrm{~mL}$ bacterial solutions were centrifuged at $4000 \mathrm{r} / \mathrm{min}$ for $15 \mathrm{~min}$. Distilled water was added to the precipitate at a material-liquid ratio of 1:10. Then, each portion of the bacterial solutions was adjusted to different $\mathrm{pH}$ values by adding $0.1 \mathrm{~mol} / \mathrm{L} \mathrm{HCl}$ or $0.1 \mathrm{~mol} / \mathrm{L} \mathrm{NaOH}$ solutions. After standing for $30 \mathrm{~min}$, we centrifuged the turbid enzyme liquid at $3000 \mathrm{r} / \mathrm{min}$ for $15 \mathrm{~min}$, filtered the precipitate, and weighed followed by drying $\left(65^{\circ} \mathrm{C}, 6 \mathrm{~h}\right)$.

\section{Extracellular enzyme activity assay}

The enzyme activity to pNPP was measured via UV/Vis absorbance at $\lambda_{\max }(405 \mathrm{~nm})$ of hydrolyzed $\mathrm{pNP}^{23}$ The preserved crude enzyme $(0.1856 \mathrm{mg} / \mathrm{mL})$ was split from a DEAESepharose FF column for the enzyme activity measurement. A $100 \mathrm{mmol} / \mathrm{L} \mathrm{pH} 6.0$ citrate buffer containing a $20 \mathrm{mmol} / \mathrm{L}$ pNPP substrate was used as a reaction medium. After staying for $15 \mathrm{~min}$ at $45^{\circ} \mathrm{C}$, we added $3 \mathrm{mmol} / \mathrm{L} \mathrm{NaOH}$ to stop the reaction and measured the OD values at $405 \mathrm{~nm}$.

The enzyme activity to phoxim and dimethoate was measured by a $\mathrm{HPO}_{4}^{-}$ion selective potentiometric method. ${ }^{24}$ The change in $\Delta E$ over time of the $\mathrm{HPO}_{4}{ }^{2-}$ produced by enzymatic hydrolysis from PAO before and after acclimation was measured, and the enzyme activity was then estimated. 

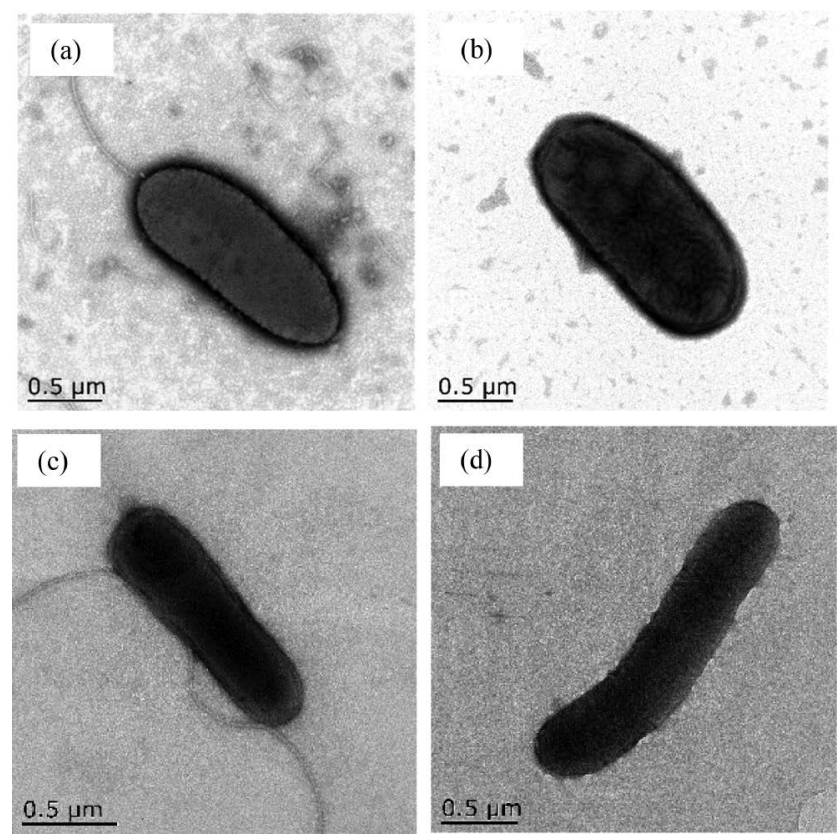

Fig. 1 TEM images of a rod-shaped PAO before and after acclimation. (a) Unacclimated spheroidal phosphorus-accumulating bacteria, (b) acclimated spheroidal phosphorus-accumulating bacteria (c) unacclimated rod-shaped phosphorus-accumulating bacteria, (d) acclimated rod-shaped phosphorus-accumulating bacteria.

\section{Reaction time of acclimated enzyme with $\mathrm{pNPP}$}

The original enzyme solution $(0.1856 \mathrm{mg} / \mathrm{mL})$ was diluted about 25 times with $100 \mathrm{mM}$ citrate buffer ( $\mathrm{pH} \mathrm{6.0)}$. We then took several branch tubes, added $1 \mathrm{~mL}$ of $20 \mathrm{mmol} / \mathrm{L}$ pNPP to each tube, and preheated the substrate and enzyme solutions separately in a $45^{\circ} \mathrm{C}$ water bath for $2 \mathrm{~min}$. We then added $1 \mathrm{~mL}$ of a preheated enzyme solution to each pNPP tubes, shook up and counted the time. When the reaction reached the corresponding time, $1 \mathrm{~mL}$ of $3 \mathrm{~mol} / \mathrm{L} \mathrm{NaOH}$ was added to terminate the reaction. The OD values at $405 \mathrm{~nm}$ were measured to determine the optimal reaction time.

\section{Optimal pH and temperature for enzyme reaction}

Same as above, $1 \mathrm{~mL}$ of purified enzyme was diluted 25 times with citrate buffer and reacted with $1 \mathrm{~mL}$ of $20 \mathrm{mmol} / \mathrm{L}$ pNPP for $15 \mathrm{~min}$ at a range of $20-80^{\circ} \mathrm{C}$. The OD values at $405 \mathrm{~nm}$ were measured. The highest enzyme activity was set to $100 \%$, and the rest was converted to a percentage of the highest activity. The $\mathrm{pH}$ effect was investigated in the range of $3.0-8.0$ at $45^{\circ} \mathrm{C}$ under the same reaction conditions described above.

Determination of $K_{m}$ and $V_{\text {max }}$ of enzyme reaction kinetic constants

The kinetic parameters of the enzyme reaction could be obtained by measuring the absorbance of the yellow watersoluble reaction product produced by the reaction of pNPP with the enzyme at $405 \mathrm{~nm}$. A series of concentrations of 2, 5, 10, $15,20 \mathrm{mmol} / \mathrm{L}$ of pNPP substrates was prepared with a citrate buffer solution (100 mmol/L, pH 6.0). Then, they were reacted with the enzyme solutions before and after acclimation at $45^{\circ} \mathrm{C}$ for $15 \mathrm{~min}$. The initial velocity, $V$, was the ordinate, and the pNPP concentration, $S$, was the abscissa to plot a graph. The $K_{\mathrm{m}}$ value and $V_{\max }$ value can be obtained by fitting the MichaelisMenten equation with Origin ${ }^{\circledR}$ software.

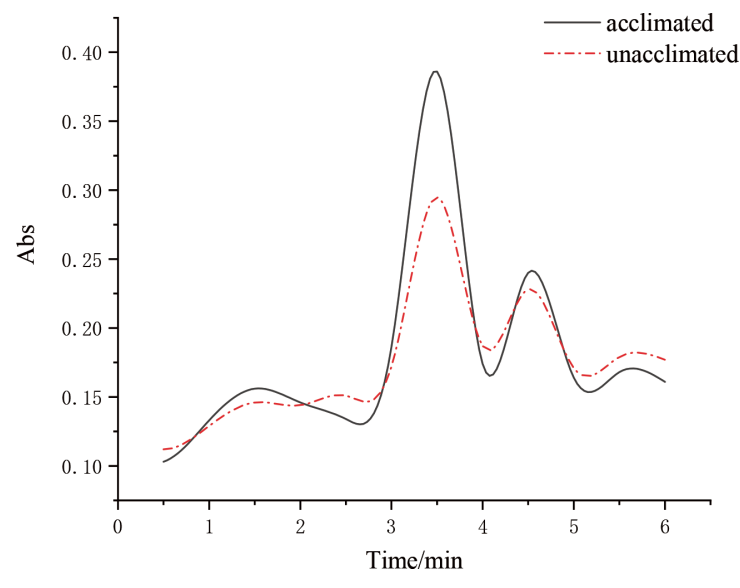

Fig. 2 DEAE-Sepharose FF anion exchange chromatogram of the extracellular enzymes secreted from PAOs before and after acclimation.

\section{Preparation of enzyme sensor}

One of the most important components of the biosensor is the immobilized biosensitive membrane, so we compared an unimmobilized pure enzyme to study the effect of the initial $\mathrm{pH}$ on the immobilized enzyme. Potentiometric enzyme electrodes were constructed with acclimated and pure enzymes, as shown in Fig. S1 (Supporting Information). The membrane was prepared by a mixture of $20 \mu \mathrm{L}$ purified enzyme from acclimated PAO (and the same quantity of non-acclimated free enzyme) with $2 \mu \mathrm{L} 10 \mathrm{wt} \%$ BSA and $5 \mu \mathrm{L} 2.5 \mathrm{wt} \%$ glutaraldehyde, and fixed on a nylon membrane by immersion, and allowed to stand at $4^{\circ} \mathrm{C}$ for $24 \mathrm{~h} .^{25}$

\section{Results and Discussion}

Isolation and cultivation of acetone-tolerant and phosphorousaccumulating bacteria colonies

After cultivation of the PAOs by the dilution coating method, the isolated colonies contained coccus, spheroidal and rodshaped bacteria, while the isolated colonies of the acclimated PAOs contained only spheroidal and rod-shaped bacteria. We initially compared the TEM images of these bacteria before and after acclimation; it can be seen that there are wrinkles on the cell surface after acclimation with flagellum abscission (Fig. 1). It may be that the addition of acetone caused the cell surface to become dehydrated with flagellum abscission. The rod and spheroidal shaped bacteria are more acetone-tolerant. Here, the rod-shaped bacteria were selected for a comparison and the applications of extracellular enzymes in subsequent experiments.

\section{DEAE-Sepharose FF anion exchange chromatography}

A crude enzyme solution was precipitated by ammonium sulfate solution, then dialyzed with a dialysis bag (MW6000). The crude enzyme solution was loaded on a DEAE-Sepharose FF anion-exchange column, and then eluted with $0.05 \mathrm{~mol} / \mathrm{L}$ Tris- $\mathrm{HCl}$ buffer and $0.5 \mathrm{mmol} / \mathrm{L} \mathrm{NaCl}(\mathrm{pH} 8.5)$ at a flow rate of $0.25 \mathrm{~mL} / \mathrm{min}$. The elution curve is shown in Fig. 2. Two protein peaks of the extracellular enzymes of PAOs were obtained, and both showed hydrolysis to OPs before and after acclimation. According to the standard curve for the determination of enzyme activity by the pNPP UV/Vis method, activities of the enzyme I and II from acclimated PAO on pNPP are 1.57 and $0.88 \mu \mathrm{mol} /(\mathrm{min} \cdot \mu \mathrm{g})$, while they are 1.14 and 


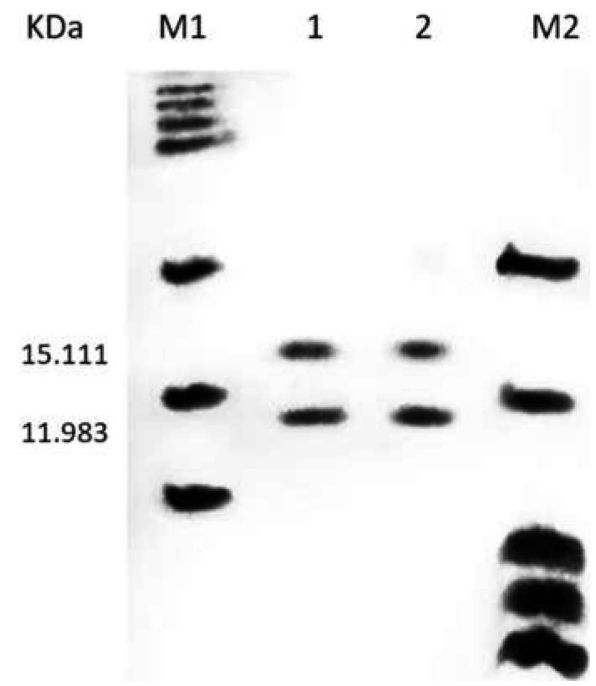

Fig. 3 Electrophoresis of extracellular enzymes of rod-shaped PAOs before and after acclimation. M1, Molecular mass standard of macromolecular protein; 1, extracellular enzyme band from unacclimated rod-shaped PAOs; 2, extracellular enzyme band from acclimated rod-shaped of PAOs; M2, molecular mass standard of small molecule protein.

$0.82 \mu \mathrm{mol} /(\mathrm{min} \cdot \mu \mathrm{g})$ in unacclimated $\mathrm{PAO}$. Both enzyme activities from acclimated PAO are slightly higher than those from unacclimated.

\section{SDS-polyacrylamide gel electrophoresis}

SDS-polyacrylamide gel electrophoresis (SDS-PAGE) separations were carried out to measure the molecular weight of the enzymes. ${ }^{26}$ Pilot experimental results by a traditional SDSPAGE protocol were problematic with a molecular weight of less than $10 \mathrm{kDa} ;{ }^{27}$ an improved peptide separation technology with silver staining was employed in this experiment. The crude enzyme solution was prepared by ammonium sulfate precipitation and a dialysis membrane in the first step, followed by SDS-PAGE separation (Fig. 3). The electrophoresis pattern shows clear specific protein bands near to 15.11 and $11.98 \mathrm{kDa}$.

Figure 3 shows that there is no clear difference in the molecular weight of the enzymes from the rod-shaped PAOs before and after acclimation. However, there are possibly tens to hundreds of molecular weight differences that might not be resolved in the SDS-PAGE separation.

\section{Determination of the isoelectric point of $\mathrm{OPH}$}

The stability of a colloidal solution is the worst when the isoelectric point, conductivity, solubility, viscosity, and osmotic pressure of the protein are the smallest. Thus, there is the most precipitation. The isoelectric points of enzymes were measured by gravimetric means. The measurement results (Table S4 (Supporting Information)) show that the isoelectric points of the extracellular enzymes of the PAOs before and after acclimation are almost the same; they are all close to 7.0 with our experimental conditions.

\section{Reaction dynamics of acclimated enzyme with pNPP}

To correctly reflect the enzyme activity, the initial reaction rate ought to be measured during the period when the amount of product is directly proportional to the reaction time. According to the absorbance value of the reaction between the enzyme and the substrate before and after the acclimation (Table S5

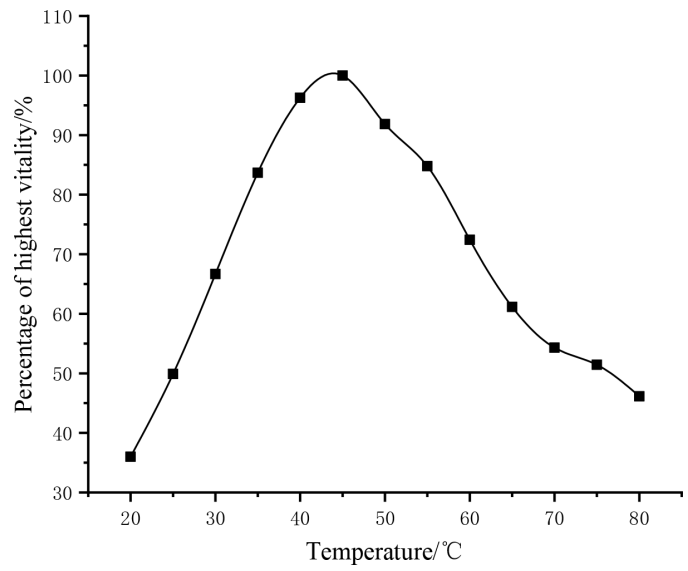

Fig. 4 Effect of temperature on the acclimated enzyme activity.

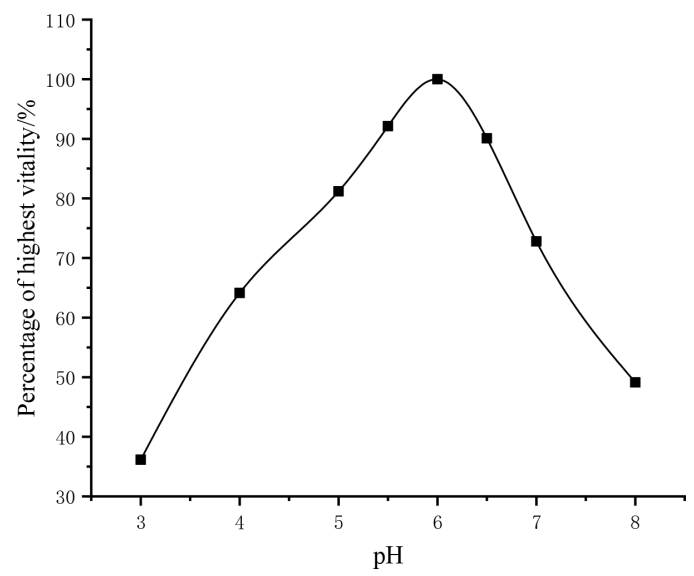

Fig. 5 Effect of $\mathrm{pH}$ on extracellular enzyme activity.

(Supporting Information)), the measurement results showed stable signals after $15 \mathrm{~min}$. Therefore, the enzymatic reaction time of the OPH from PAOs before and after acclimation was set to $15 \mathrm{~min}$.

\section{Optimum reaction temperature of enzyme}

The influence of reaction temperature on the $\mathrm{OPH}$ activity was investigated from $20-80^{\circ} \mathrm{C}$ using pNPP as a substrate (Fig. 4). The figure shows that when the reaction temperature was in $20-45^{\circ} \mathrm{C}$ the enzyme activity increased with increasing temperature, and the enzyme activity was highest at $45^{\circ} \mathrm{C}$. The initial increase in this rate is attributed to the increase in both of the enzyme reaction and mass transport rates. When the temperature was higher than $45^{\circ} \mathrm{C}$, the enzyme activity decreased as the temperature increased. This is because the enzyme gradually denatured as the temperature increases, and the activity was lost. The optimum temperature is roughly consistent with other reported hydrolysis enzymes derived from different bacteria. $^{28}$

\section{Optimal reaction $\mathrm{pH}$ of enzyme}

The influence of the $\mathrm{pH}$ on the enzymatic activity was investigated at a range of $3.0-8.0,45^{\circ} \mathrm{C}$ using pNPP as the substrate (Fig. 5). The OPH displayed above $70 \%$ of its maximal activity in the $\mathrm{pH}$ range of $4.5-7.0$ with the highest 
Table 1 Kinetic constants of $K_{\mathrm{m}}, V_{\max }$ and $K_{\text {cat }} / K_{\mathrm{m}}$ values of extracellular enzymes

\begin{tabular}{cccccc}
\hline & Enzyme + pNPP & $K_{\mathrm{m}}\left(\mathrm{mmol} \cdot \mathrm{L}^{-1}\right)$ & $V_{\max }\left(\mathrm{mmol} \cdot \mathrm{L}^{-1} \mathrm{~min}^{-1}\right)$ & $K_{\text {cat }}\left(\mathrm{s}^{-1}\right)$ & $K_{\text {cat }} / K_{\mathrm{m}}\left(\mathrm{s}^{-1} / \mathrm{mmol}^{-1}\right)$ \\
\hline \multirow{2}{*}{ Unacclimated } & Enzyme I & 19.99 & 348.7 & 1.57 & 0.078 \\
& Enzyme II & 11.93 & 107.6 & 0.48 & 0.040 \\
Acclimated & Enzyme I & 11.02 & 326.5 & 1.46 & 0.132 \\
& Enzyme II & 10.99 & 77.9 & 0.35 & 0.032 \\
\hline
\end{tabular}

activity at pH 6.0. Furthermore, the enzyme was found to be stable in the studied $\mathrm{pH}$ range; however, there was enzyme inhibition in very acidic or alkaline conditions. The reason is that changes in the $\mathrm{pH}$ to very acidic or alkaline might affect the dissociation of related groups on the active site of the enzyme molecule, causing a decrease of the binding capacity of the enzyme with the substrate. ${ }^{25,29,30}$

\section{Determination of $K_{m}$ and $V_{\max }$ of the enzyme reaction}

To determinate $K_{\mathrm{m}}$ and $V_{\max }$ of the enzymes, kinetic curves of the reaction between the OPH and different concentrations of pNPP were plotted (Table 1).

The Michaelis constant, $K_{\mathrm{m}}$, usually characterizes the firmness of the binding between the enzyme and the substrate. The $K_{\mathrm{m}}$ values of Enzyme I and Enzyme II from acclimated were lower than those of the none acclimated. The maximum reaction rate $\left(V_{\max }\right)$ can characterize the rate at which the enzyme-substrate complex dissociates into an enzyme and a product. The $V_{\max }$ value of enzyme I from acclimated PAO was slightly lower than that of from non-acclimated, and the $V_{\max }$ value of enzyme II was a little higher than that of from non-acclimated. The substitution of acetone for water during acclimation may change the substrate specificity and structure of the enzyme and its catalytic efficiency. To more clearly show the changes of the enzyme catalytic efficiency before and after acclimation, the $K_{\text {cat }} / K_{\mathrm{m}}$ values in both cases were calculated, and added in Table 1 . The $K_{\text {cat }} / K_{\mathrm{m}}$ value of enzyme I increased from 0.078 to 0.132 . However, the increase was still not significant, since we did not touch the coordinated ion in the acclimation process. As is known, the OPH property is closely related to the coordinated bivalent metal ions. ${ }^{31}$

The enzymatic activity of the immobilized enzyme to hydrophobic phoxim before and after acclimation was 0.105 and $0.164 \mu \mathrm{mol} / \mathrm{min} \cdot \mu \mathrm{g}$, respectively. The enzyme activity for phoxim improved to around 1.6-fold after acclimation.

Influence of buffer centration and initial $\mathrm{pH}$ on the enzyme sensor The buffer concentration has a remarkable influence on the rate of the potential change of the sensor, which is an inverse function of the buffer concentration. The lower detection limits were conducive to the weak buffer. Since the objective of this work was to demonstrate a simple and rapid biosensor for OPs, $10 \mathrm{mM}$ buffer was selected for subsequent $\mathrm{pH}$ studies.

The $\mathrm{pH}$ value of the enzyme electrode modified with the immobilized enzyme is roughly similar to that of the free enzyme (Fig. 6). This fact, combined with the observation that the $\mathrm{pH}$ value did not change in the control experiment (without the enzyme layer), proves that the $\mathrm{pH}$ dependence of the sensor response is due to the $\mathrm{pH}$ dependence of the enzyme activity. ${ }^{25}$ A difference of 0.5 unit between the best value of the free enzyme and the immobilized enzyme both from acclimated PAO can be attributed to the change in the physical and chemical properties of the enzyme caused by immobilization. ${ }^{25}$

Figure 6 shows higher $\Delta E / \Delta t$ values in the acclimated enzyme compared to non-acclimated ones. This explains the enzyme

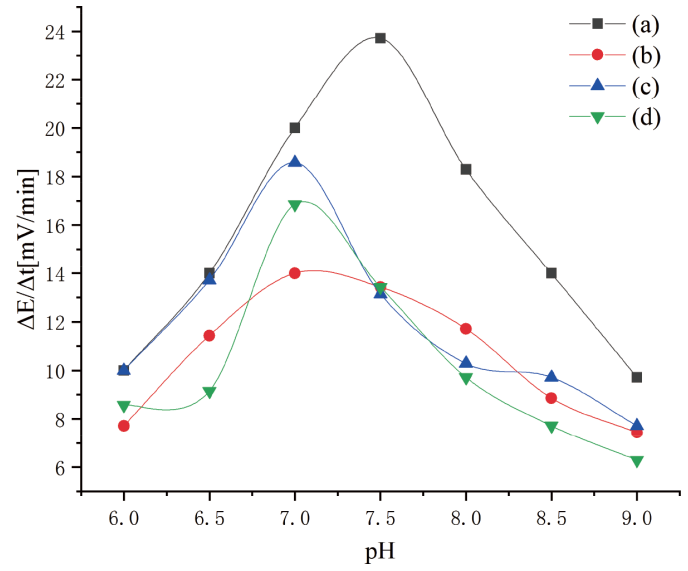

Fig. 6 Effect of the initial $\mathrm{pH}$ on free and immobilized enzymes from acclimated and non-acclimated PAO. (a) Free enzyme from acclimated PAO; (b) free enzyme from non-acclimated PAO; (c) immobilized enzyme from acclimated PAO; and (d) immobilized enzyme from non-acclimated PAO.

activity enhanced to phoxim after acetone acclimation. The difference in the immobilized $(\boldsymbol{\square})$ and free enzyme $(\boldsymbol{\bullet})$ can be attributed to activity loss in the immobilization process, since the glutaraldehyde covalent method was employed here, which might partially destroy the protein $3 \mathrm{D}$ conformation.

On the other hand, after immobilization, the change before and after acclimation became small. This indicates that the reactivity of the immobilized and free enzymes was altered. The reason might be the reduced susceptibility, owing to the steric hindrance after immobilization for acclimated enzyme as well as the above-described activity loss during immobilization $(\boldsymbol{\Delta})$, while an increased concentration effect of free enzyme on the membrane surface (in all four cases added a same quantity of enzyme) is greater than the enzyme activity loss $(\boldsymbol{\nabla})$.

The $\Delta E / \Delta t$ of the acclimated enzyme electrode from the acclimated one was about $59 \mathrm{mV}$, with a 10-times concentration difference of phoxim at $\mathrm{pH}$ 7.0. This means that high-sensitivity detection is possible if combined with other electrochemical techniques. Here, we used the normal $\mathrm{pH}$ meter for economic consideration. The stabilization time was within $60 \mathrm{~s}$. In all cases, they have the highest sensitivity, the shortest response time, and the largest dynamic range at $\mathrm{pH}$ 7.0.

Standard curve and detection limit of the demonstrated enzyme sensor

Under the optimized conditions, the calibration curve of the $\Delta \mathrm{pH}$ versus the concentration of phoxim was linear over in the range of $0.2-0.001 \mathrm{mg} / \mathrm{mL}$ (Fig. S2 (Supporting Information)). The linear regression equation of the sensor is $y=8.47 x+0.205$ $\left(R^{2}=0.9994\right)$ with the detection limit $(S / N=3)$ of $0.2 \mu \mathrm{g} / \mathrm{mL}$.

Unlike the AChE-based OPs biosensors, the present OPHbased enzyme (from acclimated PAOs with the molecular 
weight of the enzyme only ca. 12 and $15 \mathrm{kDa}$ ) electrode is highly specific for a range of hydrophilic and hydrophobic OPs, such as methamidophos, dimethoate, methyl parathion, dichlorphos, glyphosate, except phoxim, as we tested. This is a significant benefit over the AChE-based biosensors, especially for the on-line the determination of OPs in various environmental samples.

\section{Conclusions}

The acetone acclimation and isolation of PAO strains showed that spheroidal and rod-shaped PAOs colony could be obtained. Two OPHs from rod-shaped PAO could be identified through a series of separation and purification processes for extracellular enzymes released from the rod-shaped PAOs. Their molecular weights were $c a$. $15.11 \mathrm{kDa}$ and $c a .11 .98 \mathrm{kDa}$. Both of them showed hydrolase activity on disodium $p$-nitrophenyl phosphate (enzyme I, $1.57 \mu \mathrm{mol} /(\mathrm{min} \cdot \mu \mathrm{g})$; enzyme II, $0.88 \mu \mathrm{mol} /(\mathrm{min} \cdot \mu \mathrm{g}$ ) at $\left.45^{\circ} \mathrm{C}\right)$. The $\mathrm{OPH}$ activity before and after acclimation was 0.105 and $0.164 \mu \mathrm{mol} / \mathrm{min} \cdot \mu \mathrm{g}$ for phoxim, respectively.

\section{Acknowledgements}

This work was supported by Science and Technology Program Nanjing Customs, China (No. 2021KJ21).

\section{Supporting Information}

This material is available free of charge on the Web at http:// www.jsac.or.jp/analsci/.

\section{References}

1. B. K. Singh, Nat. Rev. Micobiol., 2009, 7, 156.

2. J. Sherma, Anal. Chem., 1993, 65, 40.

3. S. Yao, A. Meyer, and G. Henze, Fresenius J. Anal. Chem., 1991, 339, 207.

4. M. Rahman, A. M. A. El-Aty, S. W. Kim, S. C. Shin, H. C. Shin, and J. H. Shim, J. Sep. Sci., 2017, 40, 203.

5. P. Worsfold, I. McKelvie, and P. Monbet, Anal. Chim. Acta, 2016, 918,8

6. X. Cao, A. Hogan, and E. Moore, J. Forensic. Sci., 2019, 64, 1213.

7. C. Zhang, Z. Jiang, M. Jin, P. Du, G. Chen, X. Cui, Y. Zhang, G. Qin, F. Yan, A. M. Abd El-Atye, A. Hacimüftüoğlug, and J. Wang, Food Chem., 2020, 326, 126813.
8. S. Nagabooshanam, A. T. John, S. Wadhwa, A. Mathur, S. Krishnamurthy, and L. M. Bharadwaj, Food Chem., 2020, 323, 126784.

9. J. S. Van Dyk and B. Pletschke, Chemosphere, 2011, 82, 291.

10. T.-C. Cheng, J. J. DeFrank, and V. K. Rastogi, Chem. Biol. Interact., 1999, 120, 455.

11. Y. Dong, M. Bartlam, L. Sun, Y.-F. Zhou, Z.-P. Zhang, C.G. Zhang, Z. Rao, and X.-E. Zhang, J. Mol. Biol., 2005, $353,655$.

12. P. Kumar, K.-H. Kim, and A. Deep, Biosens. Bioelectron., 2015, 70, 469.

13. I. P. Muldachan, I. A. Muchandan, and I. Kaneva, Biosens. Bioelectron., 1999, 14, 77.

14. W. W. Mulbry and J. S. Karns, J. Bacteriol., 1989, 171, 6740.

15. D. P. Dumas, S. R. Caldwell, J. R. Wild, and F. M. Raushel, J. Biol. Chem., 1989, 264, 19659.

16. Y. Gao, S. Chen, M. Hu, Q. Hu, J. Luo, and Y. Li, PLoS One, 2012, 7, e38137.

17. C. Tarayre, H.-T. Nguyen, A. Brognaux, A. Delepierre, L. De Clercq, R. Charlier, E. Michels, E. Meers, and F. Delvigne, Sensors, 2016, 16, 797.

18. H. Kodera, M. Hatamoto, K. Abe, T. Kindaichi, N. Ozaki, and A. Ohashi, Water Res., 2013, 47, 2025.

19. S. Isken, A. Derks, P. F. G. Wolffs, and J. A. M. D. Bont, Appl. Environ. Microb., 1999, 65, 2631.

20. A. Inoue and K. Horikoshi, Nature, 1989, 338, 264.

21. L. Li, L. Long, and S. Ding, Front. Microbiol., 2019, 10, 1798.

22. W. Jiang and B.-S. Fang, Appl. Biochem. Biotech., 2020 , 190,18

23. S. Kan, S. Agarwal, and P. Pancholi, Mol. Microbiol., 2015, 97, 515.

24. Y. Li, T. Jiang, X. Yu, and H. Yang, J. Electrochem. Soc., 2016, 163, B479.

25. A. Mulchandani, S. Pan, and W. Chen, Biotechnol. Prog., 1999, 15, 130.

26. E. Yamada, K. Sasai, R. Higa, H. Mizuguchi, and Y. Fuse, Anal. Sci., 2020, 36, 753.

27. D. W. Cleveland, S. G. Fischer, M. W. Kirschner, and U. K. Laemmli, J. Biol. Chem., 1977, 252, 1102.

28. X. Fan, X. Liu, K. Wang, S. Wang, R. Huang, and Y. Liu, J. Mol. Catal. B: Enzym., 2011, 72, 319.

29. S. Wang, K. Wang, L. Li, and Y. Liu, J. Mol. Catal. B, 2013, 95, 1.

30. A. Mulchandani, K. B. Male, and J. H. T. Luong, Biotechnol. Bioeng., 2010, 35, 739.

31. S.-C. Jao, L.-F. Huang, Y. S. Tao, and W.-S. Li, J. Mol. Catal. B, 2004, $27,7$. 